\title{
Effect of Seaweed Extract Applied to Growth Media on Mycelium Growth of Oyster Mushroom
}

\author{
Golgen Bahar Oztekin (Corresponding author) \\ Ege University, Faculty of Agriculture, \\ Department of Horticulture 35100 Bornova-Izmir / Turkey \\ E-mail: golgen.oztekin@ege.edu.tr \\ Halime Kurt \\ Ege University, Faculty of Agriculture, \\ Department of Horticulture 35100 Bornova-Izmir / Turkey \\ E-mail: halimekurt0511@gmail.com
}

\begin{abstract}
This study was carried out to determine the effect of Ecklonia maxima type seaweed extract applied to growth media on mycelium growth of oyster mushroom (Pleurotus ostreatus). In the experiment, most common 2 growth media [Malt Extract Agar (MEA) and Potato Dextrose Agar (PDA)] were used. After the prepared MEA $\left(48 \mathrm{~g} \mathrm{~L}^{-1}\right)$ and PDA $\left(39 \mathrm{~g} \mathrm{~L}^{-1}\right)$ medium was autoclaved at $121^{\circ} \mathrm{C}$ for 20 minutes, half was separated and $2 \%$ E. maxima seaweed extract (DY) was added. The experiment consisted of 4 growth media: MEA, PDA, MEA + DY and PDA + DY. While the prepared environments were warm and fluidal, they were filled in petri dishes under UV light in a sterile cabinet and left to cool. After surface disinfection of oyster mushrooms, clones were taken and placed on the medium in petri dishes and petri dishes were closed with parafilm. The petri dishes $(n=15)$ were placed in the incubator at $24^{\circ} \mathrm{C}$. Daily mycelia lengths and weight of petri dishes were measured and mycelia growrth pwriod (day) and rate $\left(\mathrm{cm} \mathrm{day}^{-1}\right)$ were calculated. Among the used growth media, PDA was given more and heavier mycelia growth in a shorter time than MEA. DY application was increased mycelia growth period and reduced growth rate. DY was showed better performance in PDA medium. As a result of the research, it has been determined that the addition of liquid seaweed extract preparation to PDA at a rate of $2 \%$ (PDA + DY) increased micelle growth and shortened micelle growth period.
\end{abstract}

Keywords: PDA, MEA, Ecklonia maxima, Oyster mushroom

DOI: $10.7176 /$ JSTR/7-03-02

\section{Besi Ortamına Eklenen Deniz Yosunu Özütünün Kayın Mantarında Misel Gelişimine Etkisi}

\author{
Bu çalışma, FLP-2019-21266 proje numarası ile Ege Üniversitesi Bilimsel Araştırma Projeleri \\ (BAP) Koordinatörlüğ̈̈ tarafindan "Lisans Projesi” olarak desteklenmiştir.
}

\begin{abstract}
Özet
Ecklonia maxima türü deniz yosunu özütünün, kayın mantarında (Pleurotus ostreatus) misel gelişimi üzerine etkisini belirlemek amacı ile yürütülen bu çalışmada, besi ortamı olarak [Malt Ekstrakt Agar (MEA) ve Patates Dekstroz Agar (PDA)] kullanılmıştır. Hazırlanan MEA (48 g/L) ve PDA (39 g/L) besi ortamlar $121^{\circ} \mathrm{C}$ 'de $20 \mathrm{dk}$ otoklavlanarak sterilize edilip ılıklaştıktan sonra yarısına $\% 2$ oranında $E$. maxima deniz yosunu özütü (DY) ilave edilmiştir. Deneme MEA, PDA, MEA+DY ve PDA+DY besi
\end{abstract}

8 | $\mathrm{P}$ a g e

www.iiste.org 
ortamları olmak üzere 4 konudan oluşmuştur. Hazırlanan ortamlar 1lık ve akışkan halde iken steril kabin içerisinde UV 1 şı altında steril petri kaplarına doldurulmuş ve soğumaya bırakılmıştır. Kullanılacak kayın mantarının yüzey dezenfeksiyonu yapıldıktan sonra doku parçaları alınmış ve petri kaplarında besi ortamları üzerine yerleştirilmiş ve parafilm ile petri kapları kapatılmıştır. Hazırlanan petri kapları $(n=15) 24^{\circ} \mathrm{C}$ 'de inkübatöre yerleştirilmiştir. Günlük olarak misel uzunlukları ve petri kapları ağırlıkları ölçülmüş, misel gelişim süresi (gün) ve hızı (cm/gün) hesaplanmıştır. Kullanılan besi ortamları içerisinde PDA, MEA'a göre daha kısa sürede misel gelişimi sağlamış ve daha ağır miseller oluşturmuştur. DY uygulaması misel gelişim hızını arttırmış, süresini kısaltmıştır. DY, PDA ortamında daha iyi sonuç vermiștir. Araştırma sonucunda, sıvı deniz yosunu özütü preparatının \%2 oranında PDA'ya ilave edilmesi ile hazırlanan besi ortamının (PDA+DY) misel gelişim hızını artırdığı ve misel gelişim süresini kısalttığı tespit edilmiştir.

Anahtar Kelimler: PDA, MEA, Ecklonia maxima, İstiridye mantarı

\section{Giriş}

Günümüzde mantarların insan beslenmesi ve sağlığı açısından değerinin daha iyi anlaşılmasıyla birlikte kültür mantarı yetiştiriciliğine olan ilgi de artmıştır. Dünya yemeklik mantar üretimi 2018 yılı itibari ile 8.993.280 ton olup, üretimde \% 74.1'lik pay ile Çin birinci sırada yer almaktadır. Bunu sırasıyla ABD, Hollanda, Polonya ve İspanya takip etmektedir. Ülkemiz ise 46.144 ton üretim ile (\%0.5 üretim pay1) dünya sıralamasında on altıncı sırada yer almaktadır (FAOSTAD, 2020). TUIK verilerine göre ülkemiz 2019 yılı yemeklik mantar üretimi 49.364 ton'dur (TUIK, 2020a). Dünyada en fazla kültürü yapılan türler yaklaşık \%30 pay ile Agaricus cinsine aittir. Pleurotus cinsi yaklaşık \%27'lik bir paya sahiptir. Türkiye'de mantar üretiminin yaklaşık \%75'lik payının Agaricus cinsi; \%14'lik payının Pleurotus cinsinin oluşturduğu belirtilmektedir (Eren ve Pekşen, 2019). Günümüzde istiridye mantarı tüketimi hızla artmakta ve bununla birlikte üretimi de ciddi bir şekilde artış göstermektedir. Ancak istatistiksel kayıtlarda mantar tür bazında ayrılmadığı için Pleurotus türüne ait gerçek üretim değerlerine ulaşılamamaktadır.

Pleurotus ostreatus mantar türü (istiridye mantarı), taşıdığı ekonomik değerin yanı sıra tıbbi özelliklere de sahiptir. Yüksek besin içeriği, düşük kalorisi (İlbay, 1995; Kıvan ve Durmuş, 2020), sağlık açısından yararları (Cohen et al., 2002), tadının ete benzetilmesi ve lezzetli olması bu mantarı ayricalıklı kılmaktadır. İstiridye mantarı beyaz şapkalı mantar türünden farklı olarak, yetiştirme ortamında (kompost) fermantasyon istememekte ve örtü toprağı gerektirmemektedir. Ayrıca bu mantar türünün üretiminin kolay olması, çevresel kontrole daha az ihtiyaç duyması, hastalık ve zararlılara karşı dirençli olması istiridye mantarının üretimini diğer mantar türlerinin üretimine kıyasla daha cazip kılmaktadır (Sánchez, 2010). Üretimde devlet desteklerinin olması yanında, yatırım maliyetinin beyaz şapkalı mantar yetiştiriciliğine göre daha düşük olması ve yüksek fiyattan pazarlanması mantar üreticilerinin bu türe yönelmesine neden olmaktadır.

"Kavak, kayın, dil, kulak, melek mantarı" gibi yöresel isimlerle anılan ve ülkemiz florasında da yeri olan Pleurotus türleri 1lıman iklim bölgelerinde; kavak, kayın, meşe, karaağaç, akçaağaç, ıhlamur, söğüt, ceviz ve kestane gibi birçok ağaç türünün gövdelerinde doğal olarak kendiliğinden yetişmektedir. Ancak doğaya bağlı olarak yapılan geleneksel üretim yöntemlerinde verim değerleri düşük olmaktadır. Bu nedenle 1959 yılında belirtilen ağaç türlerinin talaşları üzerinde, 1970 yılından itibaren ise yetiştiriciliğinde hububat saplarının kullanılmaya başlamasıyla Pleurotus türlerinin ticari olarak üretilmesinde önemli adımlar atılmıştır (Doğan ve ark., 2014).

Ticari olarak yapılan üretimlerde "Tohumluk misel” adı verilen, hububat daneleri veya değişik organik maddelere sardırılmış sekonder miseller kullanılır (Günay ve ark., 1984). Bu sistem ilk kez Amerika'da 1931 yılında Sinden tarafından geliştirilmiştir (İlbay ve Günay, 1992). Agaricus ve Pleurotus cinslerine giren türlerde genellikle buğday, çavdar, darı, sorgum gibi hububat daneleri sardırma ortamı olarak değerlendirilebilmektedir (Abak, 1989).

Ülkemiz misel eldesinde dışa bağımlı olduğumuz görülmektedir. 2019 yılında ithal edilen tohumluk misel miktarı 2.573.332 kg olup, ithalatın Macaristan, Polonya, Ukrayna ve Fransa'dan yapıldığ görülmektedir (TUIK, 2020b). Ancak, ithal edilen tohumluk misellerin ülke içinde akredite olmuş laboratuvarlarda çoğaltılması şeklinde bir uygulama söz konusudur.

Tohumluk misel başlangıç materyali olması nedeni ile önemli bir materyaldir ve kalitesinin yüksek olması beklenmektedir. Misel kalitesi anaçlık materyale, üretim aşamasındaki koşullara, kullanılan dane türüne, depolanma süresine göre değişebilmektedir. Bununla birlikte tohumluk misel konusunda çalışmaların ve üretim protokollerinin az olduğu görülmektedir. Günümüzde üretim miktarı gittikçe

9 | P a g e

www.iiste.org 
artan kayın mantarının tohumluk misel üretimi ile ilgili protokolleri çeşitlendirmek ve misel kalitesini arttırmaya yönelik çalışmalara ihtiyaç vardır. Son günlerde bitkisel üretimde oldukça fazla kullanılan deniz yosunu ile ilgili yapılan çalışmalar deniz yosununun avantajları nedeni ile mantar miseli üretiminde de kullanılabilirliğini, bu yönde protokollerin ortaya konulmasını gündeme getirmiştir.

Deniz yosunları 17. yüzyıldan günümüze gıda maddesi olarak tüketilirken (Cirik ve Cirik, 2004), denize kıyısı uzun ve deniz yosunu bol olan Norveç, Finlandiya gibi ülkelerde gübre olarak değerlendirmeye başlamışlardır. Deniz yosunları çok eski zamanlardan beri gübre olarak kullanılıyorsa da deniz yosunu ekstraktlarının yapraktan püskürtülme şeklinde uygulanması daha yakın bir geçmişe sahiptir (Yazıc1 ve Kaynak, 2012).

Okyanus ve denizler vitamin, mineral ve iz elementler yönünden zengin olup, deniz yosunları bu elementleri yüksek konsantrasyonlarda absorbe etme yeteneğindedirler (Dring et al., 1986). Toprağa direk olarak karıştırıldıklarında toprak yapısının düzeltmekte, toprak verimliliğinin uzun süre korunmasına olanak vermektedir. Denizler tarafından doğal olarak kıyıya atılan bazı deniz algleri, tarlalarda gübre olarak kullanılmış ve olumlu etkileri görülmüştür (Güner ve Aysel, 1999). Blunden et al. (1992) ve Engin (2009) deniz yosunlarının tohum çimlenmesi ve çıkışını, fide gelişimini ve kalitesini arttırdığını, kök gelişimini teşvik ederek bitkilerin topraktan su ve besin maddesi alınımını arttırdığını, bitki gelişimini teşvik ettiğini, verim artışı sağladığını, bitkilerde hücre gelişimi ve bölünmesini tetikleyerek ve klorofil oluşumunu hızlandırarak daha fazla karbonhidrat, protein vb. maddelerin yapılmasını sağladığını, bitkilerin biotik ve abiyotik stres faktörlerine dirençlerini arttırdığını, meyve ağaçlarında dallanmayı ve meyve tutumunu arttırdığını, çiçek ve meyve dökümlerini azalttığını, ürünlerin depolama dayanıklılığını arttırdığını ve tarım ilaçlarının etkilerini \%25 arttırdığını bildirmişlerdir. Deniz yosunu özleri bitki gelişmesini teşvik edici maddeleri doğal olarak içermekte ve bu maddeler sayesinde abiyotik (kuraklık, tuzluluk ve düşük sıcaklık gibi) stres faktörleri altında bitki gelişmesini ve verimini artırmaktadırlar (Crouch and Staden, 1992 \& 1993; Nebati et al., 1994). Crouch et al. (1990) bitkilere uygulanan yosunlarda bitki gelişimini ve verimini etkileyen makro ve mikro besin elementler ile amino asitler, vitaminler, sitokininler, oksinler ve absisik asit (ABA) bulunduğu belirtilmişlerdir. Benzer şekilde Wilczek and Timoty (1982) deniz yosunu özünün makro ve mikro besin elementleri, amino asitleri, B1, B2, C ve E vitaminlerini, stokininler ve oksinleri içerdiklerini belirtmiştir. Bu maddelerin de (özellikle sitokinin ve oksinlerin) farklı bitki türlerinde tohum çimlenmesi ve bitki büyümesi üzerine uyartıcı etki yaptıkları belirlenmiştir (Wilczek and Timoty, 1982; Crouch and Staden, 1992; Sivritepe, 2000; Ylldırım ve ark., 2002; Sivasankari et al., 2005).

Genellikle kahverengi alglerin sıvı ekstraktları bitkisel üretimde kullanılmak üzere pazarlanmaktadır. $\mathrm{Bu}$ ekstraktların çoğu Ascophyllum nodosum yosunundan hazırlanmakla birlikte Fucus serratus, Ulva spp., Laminaria spp., Glacilariopsis türleri ve Ecklonia maxima türü deniz yosunundan oluşan bir çok ticari preparatı piyasada bulmak mümkündür. Denizden çıkarılan ve tarımda kullanılan yosun çeşitleri arasında, dünyada en fazla araştırılan ve ülkemizde de en yaygın bilinirliği ve kullanımı olan deniz bitkisi Ascophyllum nodosum olup, ticari olarak satışı yapılan deniz yosunu içerikli biyostimülantların \%90'dan fazlasını oluşturmaktadır. Oysa, denemede kullanılan ticari E. maxima yosun özütünün dünyada ve Türkiye'de en yoğun içeriğe (\%34.26) sahip deniz yosunu özütü olduğu bilinmektedir (Onakziraat, 2020).

Bitkisel üretimde baklagiller, sebzeler, meyveler ve orman ağaçlarında deniz yosunu kullanımının etkileri üzerine çok sayıda çalışma yapılmış; farklı deniz yosunlarının etki mekanizmaları ve organik tarımda kullanılabilirliği ortaya konulmuştur. Ancak yapılan literatür taramasında gerek bitkisel üretimde E. maxima türü deniz yosununa ait çalışmaların ve gerekse değişik mantar türlerinin üretiminde farklı deniz yosunu ekstraktlarının kullanımı ile ilgili çalışmaların (Molloy et al., 2003; Adyananto, 2007; Hausiku and Mupambwa, 2018) sınırlı olduğu, özelikle E.maxima türü ile kombine misel gelişim çalışmalara rastlanılmadığı görülmüştür. Bu nedenle, yürütülen bu araştırmasında, tarımda olumlu özellikleri bilinen deniz yosunlarından E. maxima türü deniz yosunu içeren ticari bir preparatın, misel gelişiminde en çok kullanılan iki ortam olan PDA ve MEA ortamlarına eklenmesi ile elde edilen besi ortamlarının kayın mantarının miseli gelişimine etkisi araştırılmıştır. Araştırma doz denemesi olmayıp, E. maxima türü deniz yosununun misel gelişiminde etkinliğinin olup olmadığının belirlenmesi üzerine kurgulanmıştır.

\section{Materyal ve Yöntem}

Araştırma Ege Üniversitesi Ziraat Fakültesi Bahçe Bitkileri Bölümü'ne ait mantar üretim ve araştırma laboratuvarında yürütülmüştür. Çalışmada tüm işlemler laboratuvara bulunan HEPA filtreli ve UV-C

10 | P a g e

www.iiste.org 
lambasına (Philips, TUV 30W/G30 T8, Polonya) sahip steril kabin (ESCO Laminar Flow Cabinet, Singapur) içerisinde gerçekleştirilmiş̧tir. İşlemler başlamadan önce kabin önce kloraklı su ile daha sonra saf etil alkol temizlenerek steril edilmiştir. Daha sonra kabin içerisindeki UV lamba açılarak 1 gece sterilizasyon için bırakılmıştır.

Araştırmada mantar miseli üretiminde en çok kullanılan iki besi ortamı olan Patates Dekstroz Agar (PDA, $39.0 \mathrm{~g} / \mathrm{L}$ ) (Merck 1.10130) ve Malt Ekstrakt Agar (MEA, $48.0 \mathrm{~g} / \mathrm{L}$ ) (Merck 1.05398) kullanılmıştır. Tartımı yapılan besi ortamları saf suda eritilerek otoklav şişelerine konularak $121^{\circ} \mathrm{C}$ ' de 20 dakika steril edilmiştir. Otoklavdan çıkan ve tutulabilecek sıcaklığa kadar soğuyan besi ortamlarının yarısına \%2 oranında Ecklonia maxima türü deniz yosunu özütü (DY) ilave edilmiştir. DY kaynağ1 olarak piyasada E. maxima içeriği en yüksek ticari preparat olan Fervelita Ecklokelp (Önak Ziraat A.Ş., İzmir) kullanılmıştır. Uygulama dozu firma beyanına göre, firmanın yaptığı Ar-Ge çalışmalarından elde edilen sonuçlara göre seçilmiş̧ir. DY ilavesi ile araştırmada 4 farklı ortam denenmiş [(1) PDA (Patates Dekstroz Agar), (2) PDA+DY (Patates Dekstroz Agar + Deniz Yosunu), (3) MEA (Malt Ekstakt Agar) ve (4) MEA+DY (Malt Ekstakt Agar + Deniz Yosunu)], DY'suz besi ortamları kontrol olarak kabul edilmiştir.

Hazırlanan besi ortamları steril tek kullanımlık polistiren $90 \times 17$ mm'lik petri kaplarına (İSOLAB, İstanbul) aktarılmıştır. Petri kaplarının dolum aşamasına geçilmeden önce tüm petrilerin dış ambalajı saf etil alkol ile dezenfekte edilmiş ve steril kabin içerisine alınmıştır. Hazırlanan besi ortamları steril kabin içerisinde petri kaplarına her kapta eşit oranda olmaları için hacimleri ölçülerek (12.5 ml/petri), dikkatlice doldurulmuştur ve hemen parafilm ile etrafları kapatılmıştır. Petri kapları 1 gece UV ışı altına bırakılmıştır.

Saf kültür eldesi için doku (klon) aşılaması yöntemi kullanılmıştır. Kullanılan kayın mantarı (Pleurotus ostreatus) taze olarak (Dal Mantar, Korkuteli/Antalya) alınmıştır. Doku parçası alınacak olan kayın mantarı \%60'lık alkollü su ile temizlenip steril kabin içerisine alınmış, UV lambalı kabin içerisinde bek ocak alevinden geçirilmiştir. Aşılamada kullanılacak tüm el aletleri (pens, neşter vs) de otoklavda $121^{\circ} \mathrm{C}^{\prime}$ de 20 dakika steril edilmiş kabin içerisinde tutulmuştur. El aletleri kullanılmadan önce ve her kullanım öncesi saf alkole batırılıp uçları bek ocağında yakılmıștır. Așılama işlemi 09.01.2020 tarihinde, steril kabin içerisinde üzerine kesilecek ebatın işaretlendiği steril bir petri kabı üzerinde yaklaşı $1 \mathrm{~cm}^{2}$ ebatlarında kesilen doku parçalarının petri kapları içerisindeki agar ortamı üzerine, petri kaplarının tam ortasına yerleştirilmesi şeklinde yapılmıştır. Aşılama sonrası hemen petri kaplarının kapakları kapatılmış ve etrafı parafilm ile sarılmıştır. Her bir deneme konusundan 15 adet petri kabı hazırlanmıştır. Hazırlanan petri kapları etiketlenerek, $24^{\circ} \mathrm{C}$ sıcaklığa ayarlı LSD göstergeli, bağımsız emniyet termostatll, doğal hava sirkülasyonlu inkübatöre (BINDER Cooled incubator KB 23 ULKB 23, Almanya) yerleştirilmiştir. Kullanılmadan önce inkübatör de kloraklı su ve sonrasında saf alkol ile steril edilmiştir.

Petri kapları inkübatöre konulduktan sonra her gün işaretlenen iki noktasından misel uzunlukları dijital kumpas yardımı ile ölçülmüştür. Ölçümler miseller petri kaplarını tamamen sarana kadar devam etmiştir. Elde edilen verilerden misel gelişim süresi (gün) ve misel gelişim hızı ( $\mathrm{cm} / \mathrm{gün}$ ) hesaplanmıştır. Petri kapları hazırlandığında (0. gün) ve her gün hassas tartı yardımı tartılmış ve ortalama ağırlık artışları (g) ile sarım sonunda toplam misel ağırlıkları $(\mathrm{g})$ belirlenmiştir.

Araştırmadan elde edilen verilerin ortalamaları alınarak, günlük değiş̧im değerleri ve yüzde farklılıkları belirlenmiştir. Veriler bilgisayarda JMP istatistik paket programında değerlendirilmiş ve ortalamalar arasındaki fark TUKEY testine göre belirlenmiştir.

\section{Bulgular}

\subsection{Misel Gelișim Süresi}

Uygulamaların misel gelişim süresi üzerine etkilerinin istatistiksel olarak önemli olduğu belirlemiştir. Misel gelişim süreleri konularına göre 5 ile 30 gün arasında değişmiştir. Bu değişim PDA ortamında 517 gün, PDA+DY ortamında 8-12 gün, MEA ortamında 22-30 gün, MEA+DY ortamında 12-17 gün olmuştur. Konularına göre ortalama sarım süresi ise 9.9 ile 25.8 gün arasında değişmiştir (Şekil 1). En erken sarım PDA+DY uygulamasından alıııken, en geç sarım MEA uygulamasından elde edilmiş ve iki uygulama arasında 15.9 günlük fark gözlenmiştir. PDA besi ortamında ortalama sarım süresi 11.8 gün iken, MEA besi ortamında bu süre 20.3 gün olmuş ve iki besi ortamı arasında 8.5 günlük fark oluşmuştur. PDA ortamında sarım süresi 13.7 gün iken ortama DY eklenmesi \%27.7 bir azalışla 9.9 günde sarım olmasına neden olmuştur. Benzer şekilde MEA besi ortamında sarım 25.8 günde olurken MEA+DY ortamında bu süre $\% 43$ azalmış ve 14.7 gün olmuştur. PDA+DY uygulaması PD, MEA ve MEA+DY uygulamasına göre sırasıyla \%27.7, \%61.6 ve \%32.7’ lik bir erkencilik sağlamıştır.

11 | P a g e

www.iiste.org 


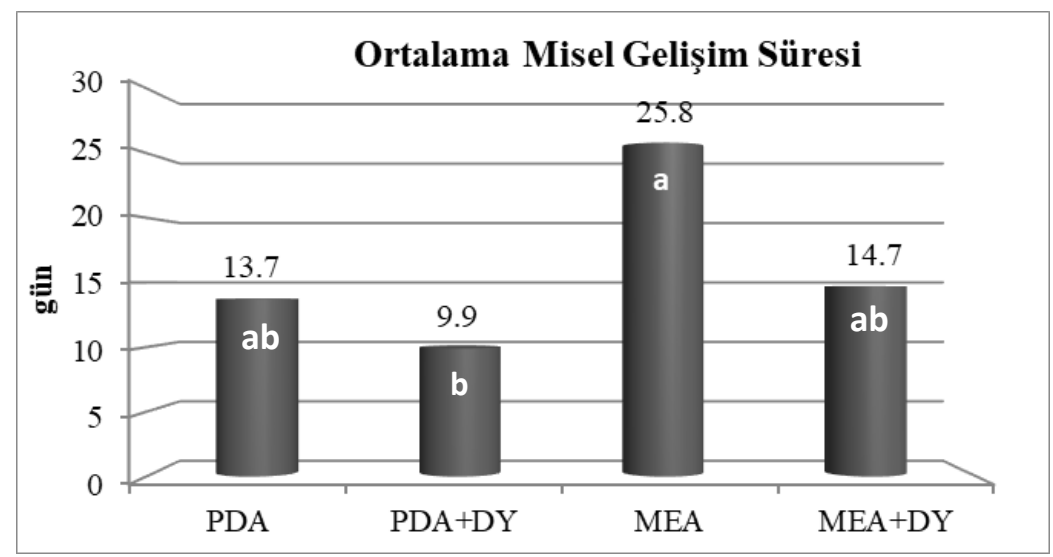

Şekil 1. Uygulamalara göre ortalama misel gelişim süresi

Figure 1. Mycelia mean growth period according to treatments

\subsection{Misel Gelişim Hızı}

Günlük misel uzunluğu olarak da ifade edilebilen misel gelişim hızı uygulamalardan istatistiksel olarak etkilenmiştir. Misel gelişim hızı 0.33 ile $3.59 \mathrm{~cm}$ arasında değişim göstermiş; bu değişimin PDA ortamında $0.90-2.62 \mathrm{~cm}$, PDA+DY ortamında $1.12-3.59 \mathrm{~cm}$, MEA ortamında $0.33-2.35 \mathrm{~cm}$ ve MEA+DY ortamında $0.64-3.73 \mathrm{~cm}$ olduğu belirlenmiştir PDA+DY uygulamasının PDA, MEA ve MEA+DY'ye göre günlük misel uzunluğunun daha fazla olduğu görülmüştür. PDA ortamında ortalama günlük misel uzunluğu $1.67 \mathrm{~cm}$ iken en hızlı gelişimin gözlendiği PDA+DY ortamında \%34.5 artışla $2.18 \mathrm{~cm}$ olmuştur. İki ortam arasında $0.56 \mathrm{~cm}$ fark meydana gelmiştir. MEA ortamında günlük misel uzunluğu $1.15 \mathrm{~cm}$ olmuş ve MEA ortamına DY eklenmesi ile günlük $0.51 \mathrm{~cm}(\% 43.7)$ artış sağlanarak ortalama günlük misel uzunluğu $1.66 \mathrm{~cm}$ olmuştur (Şekil 2).

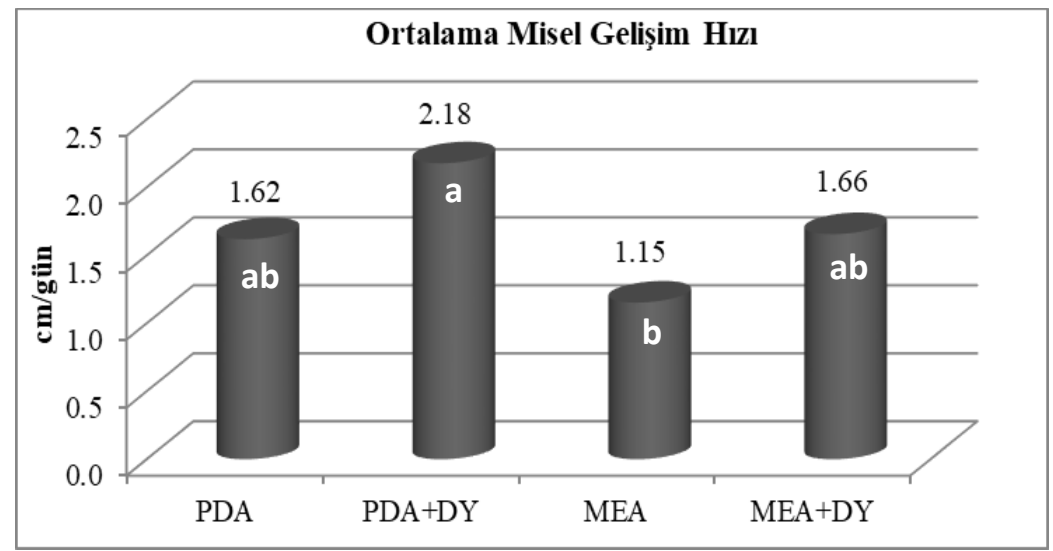

Şekil 2. Uygulamalara göre ortalama misel gelişim hızı

Figure 2. Mycelia mean growth rate according to treatments

\subsection{A}

Misel ağırlıklarının uygulamalardan istatistiksel olarak etkilendiği görülmüştür. Ortalama ağırlık artışının en fazla $0.082 \mathrm{~g} /$ petri ile PDA+DY ortamında olduğu; bunu sırasıyla $0.061 \mathrm{~g}$ ile MEA+DY, $0.052 \mathrm{~g}$ ile MEA ve $0.051 \mathrm{~g}$ ile PDA ortamları izlemiştir (Şekil 3). PDA ortamı bulunan petri kaplarının ağırlığ günlük $0.067 \mathrm{~g}$ değişirken, MEA ortamı bulunan kaplar \%18.2'lik bir azalışla günlük ortalama $0.056 \mathrm{~g}$ değişim göstermişlerdir. Buna göre ağırlık değişimi PDA ortamında 0.011-0.0143 g, PDA+DY ortaminda 0.046-0.0165 g, MEA ortamında 0.013-0.223 g, MEA+DY ortamında 0.012-0.193 g arasında olmuştur. Sarımı tamamlanan petri kaplarında ölçülen toplam misel ağırlıkları Şekil 4'de verilmiştir. Toplam ağırlık $1.066 \mathrm{~g}$ (PDA+DY) ile $0.587 \mathrm{~g}$ (MEA) arasında değişim göstermiştir. 


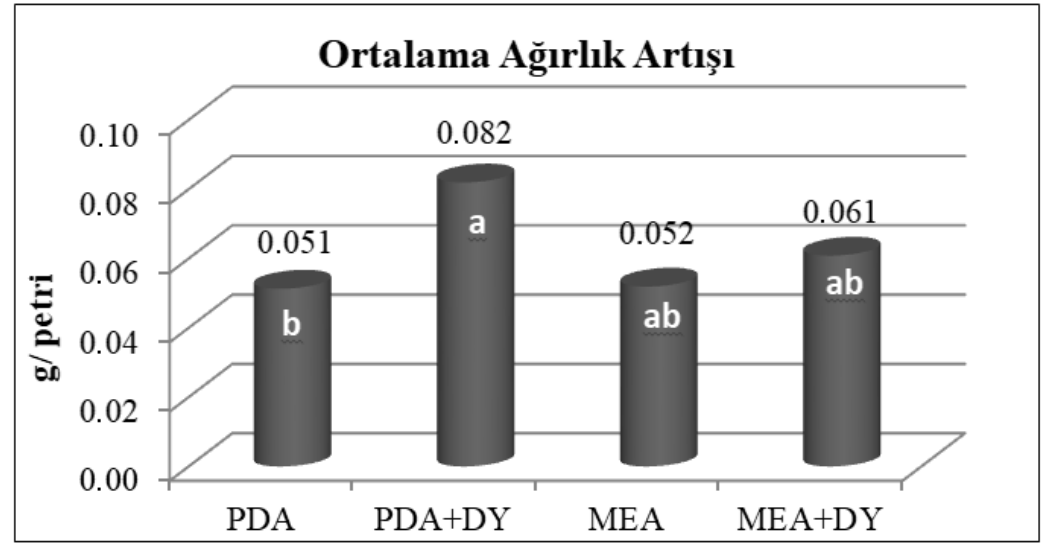

Şekil 3. Uygulamalara göre ortalama misel ağırlık artışı

Figure 3. Average weight increase of mycelia according to treatments

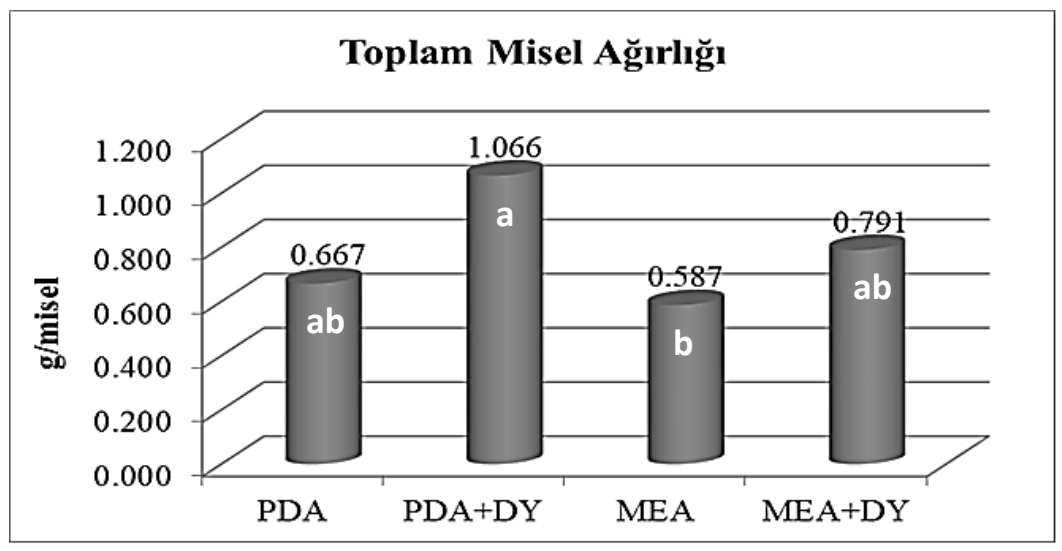

Şekil 4. Toplam misel ağırlığının uygulamalara göre değişimi

Figure 4. Change in total weight of mycelia according to applications.

\section{Tartışma, Sonuç ve Öneriler}

İnsan ve çevre sağlığına olan duyarlılığın artması ile birlikte tarımsal üretimde bitki gelişimini arttırıcı (biyostimülant) ve biyokoruyucu (biyopestisit) alternatif preparatların kullanımı gün geçtikçe önem kazanmaktadır. Deniz yosunları da böyle bir preparat olup, tarımda gerek biyostimülant (Bender Özenç ve Şen, 2017; Rouphael et al., 2017) ve gerekse biyopestisit (Ngala et al., 2016) olarak kullanılmaktadır. Deniz yosununun (DY) kayın mantarı miseli gelişiminde biyostimulant özelliğinin araştırıldığ 1 bu çalışmada, Ecklonia maxima türü deniz yosununun ilave edildiği misel üretiminde en çok tercih edilen iki besi ortamında [Patates Dekstroz Agar (PDA) ve Malt Ekstrakt Agar (MEA)] misel gelişim süresi ve hızı ile ağırlıkları, DY ilave edilmeyen besi ortamlarlari ile kıyaslanmıştır.

DY uygulamalarının bitkisel üretimde olumlu sonuçları olduğu bir çok çalışma ile ortaya knulmuştur. Mantar yetiştiriciliğinde DY kullanımı ile ilgili çalışmalar sınırlı olup, genellikle substrata misel sarımı ve ürün miktarı üzerine etkilerinin belirlenmesine yönelik olduğu görülmektedir. Farklı deniz yosunu (Ulva spp., Laminaria spp. ve Glacilariopsis spp.) karışımı ile \%5 oranında zenginleştirilmiş pirinç samanı substratında yetiştirilen $H$. ulmarius mantarında verim ve biyolojik etkinliğin kontrol ortamında yetiştirilen mantarlara göre arttırdı saptanmıştır (Hausiku and Mupambwa, 2018). Moloy at al., (2003) bira endüstrisi atıklarını farklı deniz yosunu ile karıştırarak Pleurotus sajor- caju yetiştiriciliğinde subbstrat olarak kullandıkları çalışmalarında kolonizasyon oranlarında positif sonuçlar elde etmişlerdir. Talaşa \%0, 25, 50, 75 ve 100 oranlarında katı deniz yosunu atıklarının karıştırılarak Pleurotus ostreatus ve Ganoderma lucidum mantarlarının yetiştirildiği bir çalışmada \%100 deniz yosunuatığı ortamında misel sarım hızının kontrol uygulamasından (\%100 talaş) daha hızlı olduğu ve her iki mantar türünün büyüme oranlarının ve ağırlığının saf deniz yosunu atığı ortamında yüksek olduğu saptanmıştır (Adyananto, 2007). 
Yürütülen araştırmada DY uygulamasının misel gelişimini arttırdığı, sarım süresini kısaldığı tespit edilmiştir. Yapılan literatür taramasında sonuçlarımızı destekler nitelikte invitro ortamda DY ve misel gelişimi kombinasyonu ile ilgili çalışmaya rastlanılmamıştır. Ancak Moller and Smith (1998), Sivritepe (2000), Zodape (2001), Yıldırım ve Güvenç (2005), Demir ve ark. (2006) deniz yosunu özü uygulanan birçok sebze türünde tohumlarda çimlenme oranı ve hızının arttığını belirtmiştir. Araştırmada kullanılan E. maxima DY, PDA ortamında daha iyi sonuç vermiştir. Bunun nedeninin PDA bileşimindeki karbohidrat ve patates infizyonunun misel gelişimine olan desteği olduğu düşünülmektedir.

Misel çalışmalarında genellikle ağırlık artışlarının ölçülmediği, misel gelişim hızı, misel gelişim süresi, misel koloni çapı ve misel kuru ağırlıkların belirlendiği görülmektedir (Pekşen ve Kibar, 2016). Çalışmada petri kaplarının başlangıç ağırlıklerı ile sarım tamamlanana kadar olan günlük ağırlıkları ölçlmüş ve bu değerler üzerinden günlük ortalama ağırlık artışı ve süre sonunda toplam misel yaş ağırlığı belirlenmiştir. Elde edilen verilerden, misel ağırlıklarının besi ortamlarına göre değiştiği ve besi ortamlarına eklenen DY’nin ağırlık artışını teşvik ettiği görülmüştür. Bu konuda yapılmış çalışmaların olmaması nedeni ile sonuçlar diğer sebze türleri ile kıyaslanmıştır. Bu bağlamda, Finnie and Staden (1985), Ecklonia maxima deniz yosunu özütlerinin domates bitkilerinde köklenmeyi arttırdığını, benzer şekilde Gassan et al., (1992) deniz yosunu özütünün ispanak bitkisine yapraktan spreylenmesi sonucunda ıspanak taze ağırlığının dolayısı ile verimin arttığını belirtmişlerdir. Söz konusu artışların Ecklonia maxima'nın içerdiği oksinler ile (Crouch and Staden, 1992; Yıldırım ve ark., 2002; Sivasankari et al., 2005) sağlandığ rapor edilmiştir.

Tohumluk misellerin elde edilmesinde farklı besi ortamları kullanılmakta ve doku kültürü ile değişen süreçlerle üretim yapılmaktadır. Misel gelişimi aşılama uygulamalarının doğru yapılması yanında mantar türü, kullanılan besi ortamı, sıcaklık ve $\mathrm{pH}$ derecelerine göre değişebilmektedir. Yürütülen çalışmada da kullanılan ortamlar içerisinde kayın mantarında misel gelişim süresi ve hızı açısından PDA, MEA'ya göre daha iyi sonuç vermiştir. Bulgularımızı destekler nitelikte Kalyoncu ve ark. (2008)'nın 8 farklı yabani şapkalı makrofungus türüne (Collybia dryophila, Fomes fomentarius, Gloeophyllum trabeum, Inocybe flocculosa var. crocifolia, Meripilus giganteus, Morchella hortensis, Omphalotus olearius, Postia stiptica) ait misellerin dört farklı besi ortamında [Patates Dekstroz Agar (PDA), Hagem Ortamı (HO), Minimal Ortam (MO) ve Malt Ekstrakt Agar (MEA)] sergiledikleri büyüme değerlerini araştırdıkları çalışmalarında, besi ortamları içinde en yavaş misel gelişimleri MO'da gözlenirken, PDA ve MEA besi yerlerinde misel gelişim hızları hemen hemen yakın bulunmuştur. Omphalotus olearius türünde PDA ortamında MEA ortamına göre daha hızlı bir gelişim belirlenmiştir. Bir başka araştırmada Önay ve ark. (2018) Pleurotus ostreatus mantarının misel gelişmesine MEA ve PDA besi yerlerine farklı dozlarda humik maddelerin ilavesinin misel gelişmesine etkilerini araştırmışlardır. Çalışma sonucunda PDA'nın MEA'dan daha iyi sonuç verdiği ve en hızlı gelişimin PDA'da ve \%1 hümik madde ilave edilmiş ortamda olduğunu bildirmişlerdir.

Araştırma sonucunda kayın mantarı misel geliş̧̧iminde sıvı deniz yosunu özütü preparatının \%2 oranında PDA'ya ilave edilmesi ile hazırlanan besi ortamının (PDA+DY) misel gelişim hızını artırdığı ve misel gelişim süresini kısalttığı tespit edilmiştir. Ancak farklı deniz yosunu türleri ile alternatif besi ortamlarında farklı mantar türleri, farklı gelişim sıcaklıkları ve değişik uygulama dozlarında benzer çalışmaların yapılmasına ihtiyaç duyulmaktadır.

\section{Kaynaklar}

Abak, K. (1989). Mantar misel üretimi ve doku kültüründen yararlanma. Yenilebilir Mantar Yetiştiriciliği. (Ed. S. Ağaoğlu ve M. Güler). T.O.K. Bakanlığı, Orman Genel Müdürlüğü Yayını, Ankara, s.7-17.

Adyananto, T. (2007). By product exchange of seaweed solid waste for mushrooms media. Jurnal Teknologi Lingkungan, 8(1), 1-5.

Bender Özenç, D. \& Şen, O. (2017). Farklı gelişim dönemlerinde uygulanan deniz yosunu gübresinin domates bitkisinin gelişim ve bazı kalite özelliklerine etkisi. Akademik Ziraat Dergisi, 6, 235-242.

Blunden, G., Whapham, C. \& Jenkins, T. (1992). Seaweed Extracts in Agriculture and Horticulture: Their Origins, Uses and Modes of Action, School of Pharmacy and Biomedical Science, University of Portsmouth, King Henry John Street, Hampshire P01, U.K. 202 p.

14 | P a g e

www.iiste.org 
Cirik, Ş. \& Cirik, S. (2004). Su Bitkileri: Deniz Bitkilerinin Ekolojisi, Biyolojisi ve Yetiştirme Teknikleri. Ege Üniversitesi Su Ürünleri Fakültesi Yayınları, 58, Bornova, İzmir, 188 s.

Cohen, R., Persky, L. \& Hadar, Y. (2002). Biotechnological applications and potential of wooddegrading Mushrooms of the genus Pleurotus. Applied Microbiology and Biotechnology, 58,582- 594 .

Crouch, I.J., Beckett, R.P. \& Staden, J.V. (1990). Effect of seaweed concentrate on the growth and mineral nutrition of nutrient-stressed lettuce. Journal of Applied Phycology, 2, 269-272.

Crouch, I.J. \& Staden, J.V. (1992). Effect of Seaweed Concentrate on the Establishment and Yield of Greenhouse Tomato Plants. Journal of Applied Phycology, 4, 291-296.

Crouch, I.J. \& Staden, J.V. (1993). Evidence for the Presence of Plant Growth Regulators in Commercial Seaweed Products. Plant Growth Regulation, 13, 21-29.

Demir, N., Dural, B. \& Yildırım, K. (2006). Effect of seaweed suspensions on seed germination of tomato, pepper and aubergine. Journal of Biological Sciences, 6(6), 1130-1133.

Dring, M.J., Dring, M.J. \& Dring, M.H. (1986). The Biology of Marine Plants, Edward Arnold Pty Ltd. 80 Waverley Road, Caulfield East Victoria 3145, Australia.

Doğan, N., Doğan, C. \& Hayoğlu, İ. (2014). Farklı sıcaklık ve süre uygulamalarının Pleurotus ostreatus (istiridye mantarı)'un bazı özelliklerine etkisi. Harran Tarım ve Gida Bilimleri Dergisi, 18(4), 10-16.

Engin, Y.Ö. (2009). Deniz Yosunlarının Organik Gübre Olarak Kullanımı, Doktora Tezi, Ege Üniversitesi Fen Bilimleri Enstitüsü, Bornova, İzmir, 159 s.

Eren, E. \& Pekşen, A. (2019). Türkiye'de kültür mantarı üretimi ve teknolojik gelişmeler. Mantar Dergisi, 10(3), 225-233.

FAOSTAD (2020). Crops data: Mushrooms and truffles. http://www.fao.org/ faostat/en/\#data/QC (Erişim tarihi: 07.07.2020).

Finnie, J.F. \& Staden, J.V. (1985). Effect of seaweed concentrate and applied hormones on in vitro cultured tomato roots. Journal of Plant Physiol, 120, 215-222.

Gassan, L., Jeannin, I., Lamaze, T. \& Morot, J. (1992). The effect of the Ascophyllum nodosum extract Coemar GA 14 on the growth of spinach. Botanica Marina, 35, 437-439.

Günay, A., Abak, K. \& Koçyiğit, A.E., (1984). Mantar Mantar Yetiştirme, Çağ Matbaası, 272 s. Ankara.

Güner, H. \& Aysel, V. (1999). Tohumsuz Bitkiler Sistematiği. 1. Cilt (Algler), 4. Bask1. Ege Üniversitesi Fen Fakültesi Kitaplar Serisi, Bornova, İzmir, 108: $251 \mathrm{~s}$.

Hausiku, M.K. \& Mupambwa, H. A. (2018). Seaweed amended rice straw substrate and its influence on health related nutrients, trace elements, growth and yield of edible white elm mushroom (Hypsizygus ulmarius). International Journal of Agriculture and Biology, 20, 27632769.

İlbay, M.E. (1995). Bitkisel Et: Pleurotus spp., Orman Mühendisliği, TMMOB Orman Mühendisleri Odası Yayın Organı, ss. 12-13, Ankara. 
İlbay, M.E. \& Günay, A. (1992). Yeni bir misel üretim materyali bulunabilir mi? Türkiye 4. Yemeklik Mantar Kong. Cilt I., 66-67.

Kalyoncu, F., Kalmış, E. \& Solak, M.H. (2008). Bazı makrofungus türlerine ait misellerin farklı kültür ortamlarındaki gelişim hızlarının belirlenmesi. Süleyman Demirel Üniversitesi Fen Bilimleri Enstitüsü Dergisi, 12(2), 109-114.

Kayahan, F., Kaşık, G. \& Kayahan, N. (2020). Lentinula edodes (Berk.) Pegler 1976' in misel gelişmesine humik maddeler ve giberellik asidin etkisinin araştırılması. Mantar Dergisi, 11(1),40-49.

Kıvan, O. \& Durmuş, T. (2020). İstiridye Mantarı. https://www.stb.org.tr/Dosyalar/Arastirmalar/ istiridye-mantari.pdf (Erişim tarihi:16.05.2020).

Moller, M. \& Smith, M.L. (1998). The applicability of seaweed suspensions as priming treatments of lettuce (Lactuca sativa L.) seeds. Seed Science and Technology, 26 (2), 425-438.

Molloy, F.J., Critchley, A.T., Kandjengo, L. \& Mshigeni, K.E. (2003). The use of the valuable oyster mushroom, Pleurotus sajor-caju, for conversion of waste materials produced from seaweed and brewing industries: preliminary investigations. Ambio, 76-78.

Ngala, B., Valdes, Y., Dos Santos, G., Perry, R.N. \& Wesemael, W. M. (2016). Seaweed-based products from Ecklonia maxima and Ascophyllum nodosum as control agents for the root-knot nematodes Meloidogyne chitwoodi and Meloidogyne hapla on tomato plants. Journal of Applied Phycology, 28(3), 2073-2082.

Nebati, D.A., Schmidt R.E. \& Parrish, D.J. (1994). Alleviation of salinity stres in Kentucky bluegrass by plant growth regulators and iron. Crop Science, 34, 198-202.

Onakziraat (2020). Fervelita EckloKelp Sivı Deniz Yosunu http://www.onakziraat.com.tr/ urunler/ fervelita-ecklokelp-sivi-deniz-yosunu (Erişim tarihi: 07.12.2018).

Önay, A.O., Kaşık, G., Alkan, S. \& Öztürk, C. (2018). Pleurotus ostreatus'un misel gelişmesine humik maddelerin etkisinin araştırılması. II. International Eurasian Agriculture and Natural Sciences Congress, 22--29, 11-15 Ekim 2018, Azerbaycan/Bakü.

Pekşen, A. \& Kibar, B. (2016). Effects of various carbon and nitrogen sources on mycelial biomass production of Macrolepiota procera and Polyporus squamosus in submerged culture. Anadolu Tartm Bilimleri Dergisi, 31(1), 16-24.

Rouphael, Y., De Micco, V., Arena, C., Raimondi, G., Colla, G. \& De Pascale, S. (2017). Effect of Ecklonia maxima seaweed extract on yield, mineral composition, gas exchange, and leaf anatomy of zucchini squash grown under saline conditions. Journal of Applied Phycology, 29(1), 459-470.

Sánchez, C. (2010). Cultivation of Pleurotus ostreatus and other edible mushrooms. Applied Microbiology and Biotechnology, 85,1321-1337.

Sivasankari, S., Venkatesalu V., Anantharaj M. \& Chandrasekaran M. (2005). Effect of seaweed extracts on the growth and biochemical constituents of vigna sinensis. Bioresour Technology, $18-21$.

Sivritepe, H.Ö. (2000). Deniz yosunu ekstaktı (Ascophyllum nodosum) ile yapılan ozmotik koşullandırma uygulamalarının biber tohumlarında canlılık üzerine etkileri. III. Sebze Tarımı Sempozyumu, 11-13 Eylül, 482-486. 
TUIK (2020a). Türkiye İstatistik Kurumu, Merkezi Dağıtım Sistemi, Bitkisel Üretim İstatistikleri. https://biruni.tuik.gov.tr/medas/?kn=92\&locale=tr (Erişim tarihi: 07.07.2020).

TUIK (2020b). Türkiye İstatistik Kurumu, Merkezi Dağıtım Sistemi, Dış Ticaret İstatistikleri. https://biruni.tuik.gov.tr/medas/?locale=tr (Erişim tarihi: 07.07.2020).

Wilczek, C.A. \& Timoty, J.N. (1982). Promotion of seed germination in table beet by an aqueous seaweed extract. HortScience, 17(4), 629-630.

Yıldırım, E., Dursun, A., Güvenç, İ. \& Kumlay, A.M. (2002). The effects of different salt, biostimulant and temperature levels on seed germination of some vegetable species. Acta Agrobotanica, 55(2), 75-80.

Yıldırım, E. \& Güvenç, İ. (2005). Deniz yosunu özü uygulamalarının tuzlu koşullarda pırasada tohum çimlenmesi üzerine etkisi. Bahçe, 34(2), 83-87.

Yazıc1, K. \& Kaynak, L. (2012). Deniz yosunlarının organik tarımda kullanım olanakları, http://flora.com.tr/images/PDF/deniz\%20yosunlar\%C4\%B1.pdf (Erişim tarihi: 19.05.2019).

Zodape, S.T. (2001). Seaweeds as a biofertilizer. Journal of Scientific \& Industrial Research, 60 (5),378-382. 